\title{
Factors Associated with Non-Adherence to Antiretroviral Therapy among HIV-Infected Adolescents at Pediatric Department of Yopougon University Hospital, Côte d'Ivoire
}

\section{Tanoh Kassi François Eboua ${ }^{1 *}$, Marcellin Nouaman'2, Marie-Hélène Ake-Assi' ${ }^{1}$, Yvette Bleu1, Bherat Kouadio', Ekou Niamien'1, Laurence Adonis-Koffy ${ }^{1}$}

${ }^{1}$ Pediatrics Department of Yopougon University Hospital, Abidjan, Côte d'Ivoire

${ }^{2}$ PAC CI ANRS Site, Abidjan, Côte d'Ivoire

Email: *ebouatk@yahoo.fr

How to cite this paper: Eboua, T.K.F., Nouaman, M., Ake-Assi, M.-H., Bleu, Y., Kouadio, B., Niamien, E. and Adonis-Koffy, L. (2018) Factors Associated with Non-Adherence to Antiretroviral Therapy among HIV-Infected Adolescents at Pediatric Department of Yopougon University Hospital, Côte d'Ivoire. Open Journal of Pediatrics, 8, 238-248. https://doi.org/10.4236/ojped.2018.83025

Received: July 5, 2018

Accepted: September 3, 2018

Published: September 6, 2018

Copyright ( 2018 by authors and Scientific Research Publishing Inc. This work is licensed under the Creative Commons Attribution International License (CC BY 4.0).

http://creativecommons.org/licenses/by/4.0/ (c) (i) Open Access

\begin{abstract}
Context: The consequences of non-adherence to antiretroviral therapy (ART) are harmful in terms of morbidity and mortality among HIV-infected adolescents. There is a little data in this population in West Africa, about non-adherence to ART. Objective: To identify factors associated with non-adherence to ART in adolescents at the Pediatric Ambulatory Treatment Center (PATC) of the pediatric department of Yopougon University Hospital. Materials and Methods: A cross-sectional study was conducted from May to July 2017 among adolescents aged 10 to 19 years old at PATC of pediatrics department of Yopougon University Hospital. We have considered that adolescent was not adherent to ART when he affirm that he have not taking ART at least once in the week before the survey. A logistic regression model was used to identify factors associated with non-adherence to ART. Results: Overall 166 adolescents were included. The median age was 15 years old [IQI $=13-17$ years]. They had a detectable viral load greater than $1000 \mathrm{copies} / \mathrm{ml}$ in $41.8 \%$ of cases. The rate of non-adherence to ART was $40.4 \%$. The factors associated with non-adherence to ART were male $[\mathrm{OR}=2.5(\mathrm{CI}=1.1-10.0)]$, having parent widowed $[\mathrm{OR}=7.8(\mathrm{CI}=1.6-39.3)]$ or divorced $[\mathrm{RC}=3.7(\mathrm{IC}=1.1$ 13.5)], $\mathrm{CD} 4$ inclusion rate $\geq 500$ cells $/ \mathrm{ml}[\mathrm{OR}=8.5(\mathrm{CI}=1.6-45.5)]$ and duration on $\mathrm{ART} \geq 10$ years $[\mathrm{OR}=8.9(\mathrm{CI}=1.6-50)]$. Conclusion: A rigorous therapeutic education taking into account associated factors in this study is necessary to reduce the rate of non-adherence among adolescents at PATC.
\end{abstract}

\section{Keywords}

Adolescent, Adherence, Antiretroviral Treatment, Cote d'Ivoire 


\section{Introduction}

Significant progress has been made in the fight against HIV infection since the advent of this pandemic. In fact, between 2000 and 2016, the number of new infections fell by $39 \%$ and the number of HIV-related deaths fell by a third. Access to antiretroviral treatment (ART) has saved 13 million of life in the world [1] [2]. This access to ART has resulted in better survival of HIV-infected children who reach adolescence [3]. Adolescents are a vulnerable population. Many physical and emotional changes normally occur during adolescence and many factors can compromise their adherence to ART [4].

Since 2013, to put an end to AIDS epidemic, UNAIDS recommends that $90 \%$ of people living with HIV know their HIV serologic status, that $90 \%$ HIV infected people receive sustainable ART and that $90 \%$ of people receiving ART have viral suppression load by 2020 [5]. To achieve the third target of the UNAIDS target (virological suppression), good adherence to ART is indispensable. Adherence to ART remains a challenge in the care of adolescents living with HIV [6] [7] [8] [9]. Therapeutic failure is a consequence of poor adherence to ART. It will cause persistence of viral replication. And if nothing is done we will observe the emergence of resistance to ART objectified by genotypic tests of resistance to antiretroviral molecules [9] [10] [11]. There is little data in West Africa, about non-adherence to ART among HIV-infected adolescents. In order to undertake effective actions to minimize the consequences of non-adherence in HIV-infected adolescents, it is necessary to identify the barriers to ART adherence. The objective of this study was therefore to identify the factors associated with ART non-adherence in adolescents attending at the Pediatric Ambulatory Treatment Center (PATC) of the pediatric department of Yopougon University Hospital.

\section{Materials and Methods}

A cross-sectional study was conducted at the PATC of the pediatric department of Yopougon University Hospital from May to July 2017. Adolescents aged 10 to 19 years old on ART followed for at least 6 months and with updated biological status were included (viral load, CD4 count). Adolescents with severe progressive illness (requiring hospitalization) the day of the survey were excluded. We have selected a convenience sample of adolescents attending at PATC. Eligible adolescents were systematically interviewed using a standardized questionnaire administered face-to-face during the consultation to assess the level of non-adherence. An adherence counciling has been initiated for adolescents who have not good adherence to ART (about difficulty to take ART, management of drugs adverse and reasons of difficulty of adherence to ART). Sociodemographic data (age, sex, educational level, type of housing, marital status of parents, vital status of parents), clinical data (clinical stage of the CDC), biological data (viral load and CD4 lymphocyte count) and therapeutic data (ART regimen, duration of on ART) were collected from the patient records. The clinical stage at inclu- 
sion was evaluated according to the staging of the CDC Atlanta and the level of immune depression according to the WHO classification. To define adherence to antiretroviral treatment we considered the definition of the national guide to pediatric care for HIV infection [12]. Good adherence is estimated at 90 to $95 \%$. So in our study, at least one missed ART intake in the previous week the survey was considered to define non-adherence to ART. Logistic regression was used to identify factors associated with non-adherence to ART. Odd-ratio were estimated with their $95 \%$ confidence intervals. A p-value $<0.05$ was considered statistically significant. Statistical Analyzes were done with Stata software (Stata ${ }^{\mathrm{Tm}}$ 12.0 College Station, Texas, USA).

\section{Results}

\subsection{Characteristics of the Study Population}

Overall, $449 \mathrm{HIV}$-infected children on ART are followed at PATC. Of them, 310 adolescents are between 10 and 19 years old. In this study 166 was included. The median age was 15 years (IQI = 13 - 17). The sex ratio was 1 . Adolescents with a Secondary or higher education level accounted for the majority of the sample (74.7\%). They lived in a common court or in individual housing respectively in $36.5 \%$ and $63.5 \%$ of cases. They came from parents who were married (57.1\%), divorced or separated $(22.9 \%)$ and widowed $(20 \%)$. They were fatherless in $24.2 \%$ and motherless in $29.3 \%$ of cases. At baseline, adolescents had CDC clinical stage A, B, and C respectively in $48.2 \%, 38.6 \%$ and $13.2 \%$ of cases.

They had severe immunosuppression at baseline (CD4 count $\leq 200 \mathrm{cel} / \mathrm{mm}^{3}$ ) in $15.1 \%$ of cases.

Undetectable viral load was found in $43.0 \%$ of cases. They had a viral load less than 1000 copies in $14.6 \%$ of cases. The antiretroviral regimen was based on zidivudine, tenofovir and lopinavir, respectively, in $54.8 \%, 39.2 \%$ and $2.4 \%$ of cases. The average duration of ART was 10 years.

Table 1 and Table 2 show the distribution of adolescents by level of adherence to ART.

\subsection{Factors Associated with Non-Adherence to ART}

Factors associated with non-adherence to ART are shown in Table 3 and Table 4.

In multivariate analysis, the factors associated with non-adherence to ART were sex, marital status of parents, baseline CD4 count, and duration of antiretroviral therapy. Girls were less likely to be non-adherence to ART than boys $[\mathrm{OR}=0.4(95 \% \mathrm{CI}=0.1-0.9)]$. Adolescents with separated or divorced parents $[\mathrm{OR}=3.7(95 \% \mathrm{CI}=1.1-13.5)]$ and adolescents with widowed parents $[\mathrm{OR}=$ $7.8(95 \% \mathrm{CI}=1.6-393)]$ were more likely to be non-adherent to ART.

Adolescents with no immune deficiency $\left(\mathrm{CD} 4\right.$ count $\left.>500 \mathrm{cel} / \mathrm{mm}^{3}\right)$ had a higher risk to be non-adherent to ART [OR $=8.5(95 \% \mathrm{CI}=1.6-45.5)]$. A duration on ART more than 10 years in adolescents increased the risk of being non-adherent. 
Table 1. Sociodemographic characteristics of adolescents according to adherence to ART, $\mathrm{n}=166$.

\begin{tabular}{|c|c|c|c|c|}
\hline Socio-demographic variable & $\begin{array}{c}\text { Adherence } \\
\text { N (\%) }\end{array}$ & $\begin{array}{c}\text { Non-adherence } \\
\text { N (\%) }\end{array}$ & Total n (\%) & $\mathrm{p}$ \\
\hline Median age (IQI) (years) & $16(13-17)$ & $15(13-17)$ & $15(13-17)$ & \\
\hline Level of education & & & & 0.97 \\
\hline Never schooled & $2(2.0)$ & $1(1.6)$ & $3(1.8)$ & \\
\hline Primary & $23(23.5)$ & $15(23.4)$ & $38(23.5)$ & \\
\hline Secondary/Higher & $73(74.5)$ & $48(75.0)$ & $121(74.7)$ & \\
\hline missing & 1 & 3 & 4 & \\
\hline Type of dwelling & & & & 0.98 \\
\hline Common court & $33(36.7)$ & $23(36.5)$ & $56(36.6)$ & \\
\hline Individual housing & $57(63.3)$ & $40(63.5)$ & $97(63.4)$ & \\
\hline missing & 9 & 4 & 13 & \\
\hline Marital status of parents $n=111$ & & & & 0.37 \\
\hline Live as husband and wife/married & $40(57.1)$ & $18(43.9)$ & $58(52.3)$ & \\
\hline Divorced/separated & $16(22.9)$ & $11(26.8)$ & $27(24.3)$ & \\
\hline Widowed & $14(20.0)$ & $12(29.3)$ & $26(23.4)$ & \\
\hline Missing & 29 & 16 & 55 & \\
\hline Vital status of mothers & & & & 0.25 \\
\hline Alive & $70(70.7)$ & $41(62.1)$ & $111(67.3)$ & \\
\hline Dead & $29(29.3)$ & $30(37.9)$ & $54(32.7)$ & \\
\hline Missing & 0 & 1 & 1 & \\
\hline Vital status of father & & & & 0.01 \\
\hline Alive & $75(75.8)$ & $38(56.7)$ & $113(68.1)$ & \\
\hline Dead & $24(24.2)$ & $29(43.3)$ & $53(31.9)$ & \\
\hline Father/Mother Couple $n=165$ & & & & 0.02 \\
\hline Alive & $91(91.9)$ & $53(80.3)$ & $144(87.3)$ & \\
\hline Dead & $8(8.1)$ & $13(19.7)$ & $21(12.7)$ & \\
\hline Missing & 0 & 1 & 1 & \\
\hline
\end{tabular}

Table 2. Clinical, immune-virological and therapeutic characteristics according to adherence to ART, $\mathrm{n}=166$.

\begin{tabular}{ccccc}
\hline $\begin{array}{c}\text { Clinical, biological and therapeutic } \\
\text { variable }\end{array}$ & $\begin{array}{c}\text { Adherence } \\
(\%)\end{array}$ & $\begin{array}{c}\text { Non-adherence } \\
\mathbf{n}(\%)\end{array}$ & Total $\mathbf{n}(\%)$ & p \\
\hline CDC Clinical stage & & & & 0.12 \\
Stage A & $52(52.5)$ & $28(41.8)$ & $80(48.2)$ & \\
Stage B & $34(34.3)$ & $30(44.8)$ & $64(38.6)$ & \\
Stage C & $13(13.2)$ & $9(13.4)$ & $22(13.2)$ & \\
CD4 inclusion rate & & & & 0.05 \\
$\leq 200$ & $19(19.2)$ & $6(9.0)$ & $25(15.1)$ & \\
$200-500$ & $27(27.3)$ & $19(28.4)$ & $46(27.7)$ & \\
\hline
\end{tabular}




\section{Continued}

\begin{tabular}{|c|c|c|c|c|}
\hline$>500$ & $53(53.5)$ & $42(62.6)$ & $95(57.2)$ & \\
\hline Viral load & & & & 0.16 \\
\hline Undetectable & $45(47.9)$ & $28(38.9)$ & $73(44.0)$ & \\
\hline$<1000$ copies & $20(21.3)$ & $4(5.6)$ & $24(14.5)$ & \\
\hline$>1000$ copies & $29(30.8)$ & $40(55.5)$ & $69(41.5)$ & \\
\hline$A R V$ regimen $n=160$ & & & & 0.16 \\
\hline AZT... & $57(60.6)$ & $34(51.5)$ & $91(56.9)$ & \\
\hline TDF... & $34(36.2)$ & $31(47.0)$ & $65(40.6)$ & \\
\hline$\ldots \mathrm{LPV} / \mathrm{r}$ & $3(3.2)$ & $1(1.5)$ & $4(2.5)$ & \\
\hline Missing & 5 & 1 & 6 & \\
\hline Daily ART dose & & & & 0.42 \\
\hline Single-dose & $48(49.0)$ & $30(46.2)$ & $78(48.0)$ & \\
\hline Multi-dose & $50(51.0)$ & $35(53.8)$ & $85(52.0)$ & \\
\hline Missing & 1 & 2 & 3 & \\
\hline Galenic form of ART & & & & 0.40 \\
\hline Dispersible tablets & $8(9.2)$ & $1(1.6)$ & $9(6.0)$ & \\
\hline Dry tablets & $74(85.1)$ & $56(90.3)$ & $130(87.2)$ & \\
\hline Dry tablets + dispersible tablets & $5(5.7)$ & $5(8.1)$ & $10(6.8)$ & \\
\hline Missing & 12 & 5 & 17 & \\
\hline Duration on ART (years) & & & & 0.03 \\
\hline $0-5$ & $27(29.3)$ & $10(15.6)$ & $37(23.7)$ & \\
\hline $0-10$ & $37(40.2)$ & $25(39.1)$ & $62(39.7)$ & \\
\hline$>10$ & $28(30.5)$ & $29(45.4)$ & $57(36.6)$ & \\
\hline Missing & 7 & 3 & 10 & \\
\hline Help in taking ART $n=161$ & & & & 0.41 \\
\hline Mother & $37(38.5)$ & $23(35.4)$ & $60(37.3)$ & \\
\hline Father & $16(16.7)$ & $7(10.8)$ & $23(14.3)$ & \\
\hline Father and mother & $10(10.4)$ & $10(15.4)$ & $20(12.4)$ & \\
\hline All family members & $23(24.0)$ & $18(27.7)$ & $41(25.5)$ & \\
\hline Other & $10(10.4)$ & $7(10.7)$ & $17(10.5)$ & \\
\hline Missing & 3 & 2 & 5 & \\
\hline
\end{tabular}

Table 3. Sociodemographic factors associated with non-adherence to ART.

\begin{tabular}{cccccc}
\hline Socio-Demographic Variable & & \multicolumn{2}{c}{ Univariate analysis } & \multicolumn{2}{c}{ Multivariate analysis } \\
\hline & $\mathrm{n} / \mathrm{N}$ & OR (CI 95\%) & $\mathrm{p}$ & OR (CI 95\%) & $\mathrm{p}$ \\
\hline Sex & & & 0.63 & & 0.04 \\
Male & $35 / 83$ & 1 & & 1 & \\
Female & $32 / 83$ & $0.7(50.4-1.6)$ & & $0.4(0.1-0.9)$ & \\
Age (years) & & & 0.68 & & \\
$\leq 13$ & $18 / 50$ & 1 & & & \\
\hline
\end{tabular}




\section{Continued}

\begin{tabular}{|c|c|c|c|c|c|}
\hline $13-18$ & $34 / 83$ & $1.2(0.6-2.5)$ & & & \\
\hline$\geq 18$ & $15 / 33$ & $1.5(0.6-3.6)$ & & & \\
\hline Level of education & & & 0.97 & & \\
\hline Never schooled & $01 / 03$ & 1 & & & \\
\hline Primary & $15 / 38$ & $1.3(0.1-15.6)$ & & & \\
\hline Secondary/higher & $48 / 121$ & $1.3(0.1-14.9)$ & & & \\
\hline Type of dwelling & & & 0.98 & & \\
\hline Common court & $23 / 56$ & 1 & & & \\
\hline Individual housing & $40 / 97$ & $1.1(1.2-4.6)$ & & & \\
\hline Vital status of father & & & 0.01 & & \\
\hline Alive & & 1 & & & \\
\hline Dead & & $2.4(1.2-4.6)$ & & & \\
\hline Vital status of mothers & & & 0.25 & & \\
\hline Alive & $38 / 113$ & 1 & & & \\
\hline Dead & $29 / 53$ & $1.5(0.7-2.8)$ & & & \\
\hline Father/mather couple & & & 0.03 & & \\
\hline Alive & $53 / 144$ & 1 & & & \\
\hline Dead & $13 / 21$ & $2.8(1.1-7.2)$ & & & \\
\hline Marital status of parents & & & 0.16 & & 0.001 \\
\hline $\begin{array}{l}\text { Live as husband and } \\
\text { wife/married }\end{array}$ & $18 / 58$ & 1 & & 1 & \\
\hline Divorced/separated & $11 / 27$ & $1.5(0.6-3.9)$ & & $3.7(1.1-13.5)$ & \\
\hline Veuf/veuve & $12 / 26$ & $1.9(0.7-4.9)$ & & $7.8(1.6-39.3)$ & \\
\hline Person supporting adolescent & & & 0.08 & & \\
\hline Mother & $18 / 44$ & 1 & & & \\
\hline Father & $08 / 24$ & $1.4(0.5-3.9)$ & & & \\
\hline Father and motherr & $14 / 46$ & $0.8(0.3-2.5)$ & & & \\
\hline Other & $22 / 37$ & $2.9(1.0-8.5)$ & & & \\
\hline
\end{tabular}

Table 4. Clinical, biological and therapeutic Factors associated with non-adherence with ART.

\begin{tabular}{cccccc}
\hline $\begin{array}{c}\text { Clinical, biological and } \\
\text { therapeutic variable }\end{array}$ & \multicolumn{2}{c}{ Univariate analysis } & \multicolumn{2}{c}{ Multivariate Analysis } \\
\hline & $\mathrm{n} / \mathrm{N}$ & OR (CI 95\%) & P & OR (CI 95\%) & P \\
\hline CDC Stage at inclusion & & & 0,32 & & \\
Stage A & $28 / 80$ & 1 & & & \\
Stage B & $30 / 64$ & $1.6(0.8-3.2)$ & & & \\
Stage C & $09 / 22$ & $1.3(0.5-3.4)$ & & & \\
CD4 inclusion rate & & & 0.09 & & \\
$<200$ & $06 / 25$ & 1 & & $3.5(0.6-20.0)$ & \\
$200-500$ & $19 / 46$ & $2.2(0.7-6.6)$ & & & \\
\hline
\end{tabular}




\section{Continued}

\begin{tabular}{|c|c|c|c|c|c|}
\hline$>500$ & $42 / 95$ & $2.5(0.9-6.8)$ & & $8.5(1.6-45.5)$ & \\
\hline \multicolumn{6}{|l|}{ Viral load } \\
\hline Undetectable & $45 / 73$ & 1 & & & \\
\hline$<1000$ copies & $20 / 24$ & $1.2(0.5-2.5)$ & & & \\
\hline$>1000$ copies & $29 / 69$ & $1.6(0.9-3.0)$ & & & \\
\hline ARV Regimen & & & 0.39 & & \\
\hline AZT... & $34 / 91$ & 1 & & & \\
\hline TDF.... & $31 / 65$ & $1.5(0.3-1.2)$ & & & \\
\hline$\ldots \mathrm{LPV} / \mathrm{r}$ & $01 / 04$ & $0.5(0.1-5.6)$ & & & \\
\hline Galenic Form & & & 0.09 & & \\
\hline dispersible tablets & $01 / 09$ & 1 & & & \\
\hline Dry tablets & $56 / 130$ & $6.1(0.7-49.8)$ & & & \\
\hline Dry tablets + dispersible tablets & $05 / 10$ & $8.0(0.7-90)$ & & & \\
\hline Daily ARV dose & & & 0,72 & & \\
\hline Single-dose & $30 / 78$ & 1 & & & \\
\hline Multi-dose & $35 / 85$ & $1.1(0.6-2.1)$ & & & \\
\hline Duration on ART (years) & & & 0.02 & & 0.02 \\
\hline $0-5$ & $10 / 37$ & 1 & & 1 & \\
\hline $5-10$ & $25 / 62$ & $1.8(0.7-4.4)$ & & $3.8(0.9-17.1)$ & \\
\hline$>10$ & $29 / 57$ & $2.8(1.1-6.8)$ & & $8.9(1.6-50.2)$ & \\
\hline
\end{tabular}

\section{Discussion}

\subsection{Adherence to ART}

This study specified the rate of non-adherence and the factors associated with non-adhrence to ART in adolescents at the PATC of pediatric department of Yopougon University Hospital.

Good adherence to ART in HIV-infected adolescents is essential to achieve virological suppression. Actually adherence to ART in HIV-infected adolescents remains problematic [4].

The rate of non-adherence to ART is high in this study (40.4\% of 166 adolescents interviewed). Because of the method used in this study, we would have expected a lower rate. In fact, the self-assessment method of the compliance measure may overestimate the ART adherence rate [13]. To minimize this information bias parents and adolescents have been reassured during obtaining consent. Several studies in adolescents have shown rates of non-adherence to ART between $20 \%$ and 35\% [14] [15] [16] [17]. Other study in North America and Spain among adolescents and adults estimated the non-adherence rates at $45 \%$ and $43 \%$ [18] [19]. It has been shown that the variation in the rate of non-adherence to ART observed in the studies is related to the use of evaluation method [17] [18]. 


\subsection{Factors Associated with Non-Adherence to ART}

Our study has identified epidemiological, social and biological factors associated with non-adherence to ART. Girls were likely to be less non-adherent than boys.

This result was also found in a study conducted in Zambia among 15 19-years old adolescents [20]. However, other studies have shown no significant difference between girls and boys [21]. This difference in the rate of non-adherence to ART between girls and boys HIV infected varies from one region to another. The environment in which these adolescents live might explain this difference. A qualitative study was necessary to explain this difference of adherence to ART in girl and boys adolescents HIV-infected.

Also, adolescents from divorced, separated, or widowed parents had a higher risk of being non-adherent to ART. In fact, a stable family environment in the presence of the biological parents would be a favorable environment to promote a better adherence to ART. Several studies have found that the presence of a biological parent is a factor frequently associated with good adherence to treatment [22] [23].

The absence of immune depression implying a non-advanced clinical state of the disease is a risk factor for non-adherence to ART in our study. Many studies have shown that in the early stage of the disease, adolescents are less likely to adhere to treatment [24] [25] [26]. These adolescents in relatively healthy do not find need to take their drugs. A study conducted in Uganda showed that patients hospitalized at least twice and therefore symptomatic were more likely to adhere to ART [27]. There is evidence that the level of adherence tends to decline over time in adolescents on ART and tiredness has often been the reason for non-adherence to ART in adolescents living with HIV in Uganda [28]. In our study, a duration of ART beyond 10 years increased the risk of being non-adherent at ART.

Regular compliance counseling and rigorous therapeutic education are needed to minimize the risk of non-adherence in these adolescents who are already weakened by their physical, emotional and psychological state.

\section{Conclusion}

This study shows that the level of ART non-compliance among adolescents at the Pediatric Ambulatory Treatment Center of the pediatric department of Yopougon University Hospital is high. Males, adolescents from divorced, separated or widowed parents, lack of immune depression at baseline, and duration of ART beyond 10 years were the main factors associated with non-adherence to ART. Regular compliance counseling and rigorous therapeutic education are needed to minimize the risk of non-adherence. Observational cohort studies need to be undertaken to better understand the determinants of non-adherence to ART in West Africa. 


\section{Acknowledgments}

The authors would like to thank all the study participants. They also acknowledge the support of University Hospital of Yopougon and non-governmental organization ACONDA VS.

\section{Competing Interests}

The authors declare that they have no competing interests whether financial or any other.

\section{References}

[1] OMS|VIH/sida. Consulté le 3 décembre 2017. http://www.who.int/mediacentre/factsheets/fs360/fr/

[2] ONUSIDA: Les chiffres en 2015. Consulté le 29 novembre 2016. http://www.unaids.org/sites/default/files/media_asset/AIDS_by_the_numbers_2015 fr.pdf

[3] Foster, C. and Fidler, S. (2010) Optimizing Antiretroviral Therapy in Adolescents with Perinatally Acquired HIV-1 Infection. Expert Review of Anti-infective Therapy, 8, 1403-1416. https://doi.org/10.1586/eri.10.129

[4] Musisi, S. and Kinyanda, E. (2009) Emotional and Behavioural Disorders in HIV Seropositive Adolescents in Urban Uganda. East African Medical Journal, 86, 16-24. https://doi.org/10.4314/eamj.v86i1.46923

[5] UNAIDS: Strategy Report 2016-2021. Consulté le 29 novembre 2016. http://www.unaids.org/sites/default/files/media_asset/20151027_UNAIDS_PCB37_ 15_18_EN_rev1.pdf

[6] Nachega, J.B., Hislop, M., Nguyen, H., Dowdy, D.W., Chaisson, R.E., Regensberg, L., et al. (2009) Antiretroviral Therapy Adherence, Virologic and Immunologic Outcomes in Adolescents Compared with Adults in Southern Africa. JAIDS Journal of Acquired Immune Deficiency Syndromes, 51, 65-71. https://doi.org/10.1097/QAI.0b013e318199072e

[7] Rudy, B.J., Murphy, D.A., Harris, D.R., Muenz, L. and Ellen, J. (2009) Patient-Related Risks for Nonadherence to Antiretroviral Therapy among HIV-Infected Youth in the United States: A Study of Prevalence and Interactions. AIDS Patient Care STDS, 23, 185-194. https://doi.org/10.1089/apc.2008.0162

[8] Mutwa, P.R., Boer, K.R., Asiimwe-Kateera, B., Tuyishimire, D., Muganga, N., Lange, J.M., van de Wijgert, J., Asiimwe, A., Reiss, P. and Geelen, S.P. (2014) Safety and Effectiveness of Combination Antiretroviral Therapy during the First Year of Treatment in HIV-1 Infected Rwandan Children: A Prospective Study. PLoS One, 9 , e111948.

[9] Salou, M., Dagnra, A.Y., Butel, C., et al. (2016) High Rates of Virological Failure and Drug Resistance in Perinatally HIV-1-Infected Children and Adolescents Receiving Lifelong Antiretroviral Therapy in Routine Clinics in Togo. Journal of the International AIDS Society, 19, e20683. https://doi.org/10.7448/IAS.19.1.20683

[10] Makadzange, A.T., Higgins-Biddle, M., Chimukangara, B., et al. (2015) Clinical, Virologic, Immunologic Outcomes and Emerging HIV Drug Resistance Patterns in Children and Adolescents in Public ART Care in Zimbabwe. PloS One, 10, e0144057. https://doi.org/10.1371/journal.pone.0144057

[11] Rossouw, T.M., Feucht, U.D., Melikian, G., et al. (2015) Factors Associated with the 
Development of Drug Resistance Mutations in HIV-1 Infected Children Failing Protease Inhibitor-Based Antiretroviral Therapy in South Africa. PloS One, 10, e0133452. https://doi.org/10.1371/journal.pone.0133452

[12] Ministry of Health and Public Hygiene of Côte d'Ivoire: Guide of Pediatric Care of HIV Infection. 2006 Edition, 33-34.

[13] Mukui, I.N., Ng'ang'a, L., Williamson, J., Wamicwe, J.N., Vakil, S., Katana, A. and Kim, A.A. (2016) Rates and Predictors of Non-Adherence to Antiretroviral Therapy among HIV-Positive Individuals in Kenya: Results from the Second Kenya AIDS Indicator Survey, 2012. PloS One, 11, e0167465. https://doi.org/10.1371/journal.pone.0167465

[14] Attia, S., Egger, M., Muller, M., Zwahlen, M. and Low, N. (2009) Sexual Transmission of HIV According to Viral Load and Antiretroviral Therapy: Systematic Review and Meta-Analysis. AIDS, 23, 1397-404. https://doi.org/10.1097/QAD.0b013e32832b7dca

[15] Geng, E.H., Nash, D., Kambugu, A., Martin, J.N., Zhang, Y., Braitstein, C., Christopoulos, K.A., et al. (2010) Retention in Care among HIV-Infected Patients in Resource-Limited Settings: Emerging Insights and New Directions. Current HIV/AIDS Reports, 7, 234-244. https://doi.org/10.1007/s11904-010-0061-5

[16] Talisuna-Alamo, S., Colebunders, B., Ouma, J., Sunday, P., Ekoru, K., Wabwire-MAngeni, F., et al. (2012) Socioeconomic Support Reduces Non Retention in a Comprehensive, Community-Based Antiretroviral Therapy Program in Uganda. JAIDS Journal of Acquired Immune Deficiency Syndromes, 59, e52-e59. https://doi.org/10.1097/QAI.0b013e318246e2aa

[17] Chandwani, S., Loenig, L.J., Sill, A.M., Abramowitz, S., Conner, L.C., D’Angelo, L., et al. (2012) Predictors of Antiretroviral Medication Adherence among a Diverse Cohort of Adolescents with HIV. Journal of Adolescent Health, 51, 242-251. https://doi.org/10.1016/j.jadohealth.2011.12.013

[18] Bakanda, C., Birungi, J., Mwesigwa, R., Nachega, J.B., Chan, K., Mills, E., et al. (2011) Survival of HIV-Infected Adolescents on Antiretroviral Therapy in Uganda: Findings from a Nationally Representative Cohort in Uganda. PLoS ONE, 6, e19261. https://doi.org/10.1371/journal.pone.0019261

[19] Wiens, M.O., MacLeod, S., Musiime, V., Senyonga, M., Kizza, R., Bakeera-Kitaka, S., et al. (2012) Adherence to Antiretroviral Therapy in HIV-Positive Adolescents in Uganda Assessed by Multiple Methods. Pediatric Drugs, 14, 331-335.

https://doi.org/10.1007/BF03262238

[20] Denison, J.A., Packer, C., Stalter, R.M., Banda, H., Mercer, S., Nyambe, N., Katayamoyo, P., Mwansa, J.K. and McCarraher, D.R. (2017) Factors Related to Incomplete Adherence to Antiretroviral Therapy among Adolescents Attending Three HIV Clinics in the Copperbelt, Zambia. AIDS and Behavior, 22, 996-1005. https://doi.org/10.1007/s10461-017-1944-x

[21] Kim, M.H., Mazenga, A.C., Yu, X., Ahmed, S., Paul, M.E., Kazembe, P.N. and Abrams, E.J. (2017) High Self-Reported Non-Adherence to Antiretroviral Therapy amongst Adolescents Living with HIV in Malawi: Barriers and Associated Factors. Journal of the International AIDS Society, 20, e21437. https://doi.org/10.7448/IAS.20.1.21437

[22] Petersen, I., Bhana, A., Myeza, N., Alicea, S., John, S., Holst, H., et al. (2010) Psychosocial Challenges and Protective Influences for Socio-Emotional Coping of HIV+ Adolescents in South Africa: A Qualitative Investigation. AIDS Care, 22, 970-978. https://doi.org/10.1080/09540121003623693 
[23] Denison, J.A., Banda, H., Dennis, A.C., Packer, C., Nyambe, N., Stalter, R.M., et al. (2015) "The Sky Is the Limit": Adhering to Antiretroviral Therapy and HIV Self-Management from the Perspectives of Adolescents Living with HIV and Their Adult Caregivers. Journal of the International AIDS Society, 18, e19358. https://doi.org/10.7448/IAS.18.1.19358

[24] Firdu, N., Enquselassie, F. and Jerene, D. (2017) HIV-Infected Adolescents Have Low Adherence to Antiretroviral Therapy: A Cross-Sectional Study in Addis Ababa, Ethiopia. The Pan African Medical Journal, 27, e80.

https://doi.org/10.11604/pamj.2017.27.80.8544

[25] Biressaw, S., Abebe, M., Taye, W. and Belay, M. (2013) Adherence to Antiretroviral Therapy and Associated Factors among HIV Infected Children in Ethiopia: Unannounced Home-Based Pill Count versus Caregivers' Report. BMC Pediatrics, 13, 132. https://doi.org/10.1186/1471-2431-13-132

[26] Gibb, D.M., Goodall, R.L., Giacomet, V., et al. (2003) Adherence to Prescribed Antiretroviral Therapy in Human Immunodeficiency Virus-Infected Children in the PENTA 5 Trial. The Pediatric Infectious Disease Journal, 22, 56-62. https://doi.org/10.1097/00006454-200301000-00015

[27] Catz, S. and McClure, J.B. (1998) HIV Outpatient Adherence: Relation of Disease Status to Appointment Keeping. The International AIDS Conference, 12, 864.

[28] Nabukeera-Barungi, N., Elyanu, P., Asire, B., Katureebe, C., Lukabwe, I., Namusoke, E., Musinguzi, J., Atuyambe, L. and Tumwesigye, N. (2015) Adherence to Antiretroviral Therapy and Retention in Care for Adolescents Living with HIV from 10 Districts in Uganda. BMC Infectious Diseases, 15, e520.

https://doi.org/10.1186/s12879-015-1265-5 